\title{
Domenico Scarlatti and his Cantabile Sonatas
}

\author{
ROSALIND HALTON
}

'Cantabile'. So wrote J. S. Bach over the viola part at a radiant moment midway through the third movement of the fifth Brandenburg concerto. In the preceding 20 bars, the top line is the focal point, projected powerfully through the doubling of flute and violin 1 . The cantabile marking emphasises the importance of a new melodic line doubled in violin 2 and viola, which unexpectedly enriches the texture from within. It may be one of the earliest examples of a score to carry an explicit indication to an inner part to take centre stage, in much the same way as the phrase bervortretend ('coming forward') was to be adopted centuries later by composers of the Second Viennese School.

How would the players react to this perhaps unprecedented indication? 'With a rich, warm tone' might be the obvious answer, but to eighteenth-century players, there might be equally important answers and implications- with longer sounds than those used by the players of the upper parts'; or 'with a sense of the scope of the melodic phrase, imparting fewer main accents and less space between long and short notes than would usually be given to a dotted rhythm'. Combined with the inner part indication, the flute and violin are marked pio to signal the sudden change of balance.

A number of possibilities occur when we see the marking 'cantabile', especially in the early examples of its use. If J. S. Bach was at the vanguard with his Brandenburg concerto score, Domenico Scarlatti's taste for using the term is extraordinary for the period in which he composed, particularly given the nature of the solo instrument for which his sonatas were apparently destined-the harpsichord.

According to performance manuals and contemporary accounts, eighteenthcentury violinists, oboists, flautists and trumpeters pursued the ideals of fine singing. But the term cantabile is not commonly associated with harpsichord playing. The well-known sound characteristic of a comparatively rapid decay, coupled

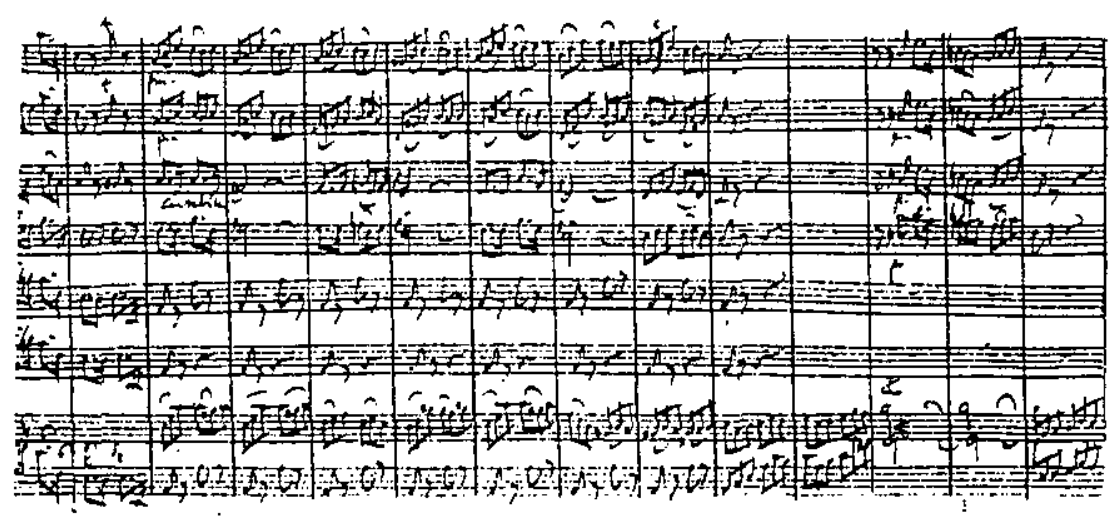

Example 1

J.S. Bach: Brandenburg Concerto No. 5, third movement, bars $148-55$ from the cantabile section Source: Facsimile of autograph, Deutsche Stantsbibliothek, Berlin. Leipzig: Edition Peters, c. 1947. 
with the impossibility of changing the dynamic quality of the sound by pressure of the finger, seems to present the player with insuperable problems in achieving a 'singing style'. Why then would a keyboard player working in Italy, Spain and Portugal in the first half of the eighteenth century use the term cantabile not once or twice, but with increasing regularity to characterise his pieces in slower tempo? What might cantabile mean to Scarlatti and those who performed his music in the eighteenth century?

'With a singing tone' reads the typical textbook definition. 'Round and complete', said Quantz ( $1752:$ 105), on the subject 'Of good performance in general'. A good performance to the eighteenth-century musician was, by definition, one in which the virtues of fine singing were present: clear enunciation, breathing in the right places, a 'round' (i.e. not edgy) sound; maybe a sound that contained, within a phrase, a specific relationship of attack and decay associated with the performance of admired singers. Quantz (1752) emphasises the reciprocal nature of fine playing and singing:

Ein jeder Instrumentist muss sich bemühen, das Cantable so vorzutragen, wie es ein guter Sänger vorträgt. Der Sänger hingegen muss im Lebhaften, das Feuer guter Instrumentisten, so viel die Singstimme dessen fähig is, zu erreichen suchen. (Vom guten Vortrage im Singen und Spielen überbaupt, 1752: 110)

Every instrumentalist should take pains to perform cantabile as a good singer does. The singer on the other hand, must aim to achieve the fiery quality of good instrumentalists, to the extent that the voice is capable of it. (On good performance in singing and playing in general)

Some thirty years before Quantz's Essay appeared, J. S. Bach (I723) used a similar turn of phrase to guide the keyboard student opening a copy of his inventions and sinfonias: the student should 'strive above all for a cantabile style of playing' ('am allermeisten aber eine cantablen Art im Spielen zu erlangen', J. S. Bach's italics.) A generation later, C. P. E. Bach went further in the Introduction to his Essay on the True Art of Playing Keyboard Instruments:

Ein grossen Nutzen und Erleichterung in der ganze Spiel-Art wird derjenige spüren, welcher zu gleicher Zeit Gelegenheit hat, die Singe-Kunst zu lernen, und gute Sänger fleissig zu hören (C. P. E. Bach, 1759: 8).

The whole approach to the art of playing will be greatly aided and simplified for those who have at the same time the opportunity to study singing, and to listen carefully to good singers.

Thus the aim of acquiring a singing style was recognised as the highest goal by the finest German keyboard players and teachers of the first half of the eighteenth century. Neither C. P. E. Bach nor his father appear to have distinguished between clavichord and harpsichord in their comments on acquiring the characteristics of a fine singing style, but both may have assumed the clavichord was the preferable instrument on which to practise the art, with its capacity to lengthen the sound (Tragen des Tones) and to impart vibrato, the characteristic closest to the quality of the voice.

Though Domenico Scarlatti can hardly have known these practical north German texts on the aesthetics of performance, he grew up in an environment where the opportunity to listen carefully to fine singing was ever present. As the son of Italy's foremost composer of vocal music, he would have accompanied 
rehearsals and performances of cantata, opera and oratorio from his earliest days, and it was in the company of the great castrato Nicolini that he first travelled extensively in Italy. Among his youthful compositions are several operas, and he. went on to compose a number of masterly solo and duet cantatas. In his later decades at the court of Maria Barbara of Spain, he became the close associate of the virtuoso castrato Farinelli, thus being exposed to singing at the highest level, prompting his interest in the art and technique of the solo singer. Thus the influence of singing may be regarded as a highly important element in the tradition inherited by Domenico Scarlatti.

In his sonatas we find cantabile used as a specific direction either on its own (e.g. K. 534 and 536) or alongside a tempo indication, ranging from Adagio (K. 208) to Andante (K. 485) and/or Moderato (e.g. K. I70 Andante moderato e cantabile). The term appears at the head of nearly twenty Scarlatti sonatas.

What kind of response did Scarlatti expect of the keyboard player in his uncommonly frequent use of the term cantabile? How would one's style of playing differ from those pieces not thus marked? Is Scarlatti signalling a style of composing by his use of the term? Or is he signalling a way of playing, or a choice of instrument? The fiery quality of Scarlatti's own keyboard performance is documented by devotees such as Irish harpsichordist Thomas Roseingrave (1688-1766) but the singing style of his adagio playing has received less attention. It was clearly important to the composer himself; the gentler side, perhaps, of a creative individuality that was regularly in contact with the taste and sensibility of Queen Maria Barbara, his principal student and admirer.

For a specifically Italian eighteenth-century approach to defining cantabile, we may look to the writings of the violinist and pedagogue Giuseppe Tartini (1692-1770), notably in his Regole per arrivere a saper ben suonar il violino ('Rules to develop knowledge of good violin playing'), first published as Traité des Agréments de la Musigue, Paris, 1771). Here Tartini emphasises the contrast between cantabile and its opposite, suonabile, in an extensive opening discussion of style and expression (Regole per le Arcate-'Rules for bow strokes'). The distinction is so important to Tartini that he devotes the first whole paragraph to it, and much of the remaining introduction.

Si deve distinguere nel Suonare il Cantabile, dal Sonabile [sic], cioè suonando il Cantabile da una nota all'altra con un unione così perfetta, che non vi si senta alcun vacuo; ed al contrario il Sonabile dev'esser eseguito con qualche distacco da una nota, ail'altra. Per distinguere quale sia Cantabile, e quale Sonabili, osservisi che quegl'andamenti, che vanno di grado, questi sono li Cantabili, e per conseguenza devonsi esprimere con unione, e senza vacuo; quegli'andamenti, che vanno di salti, questi saranno li Suonabili, e si dovranno esprimere col suo distacco. (facs. ed. Jacobi 1961: 2)

One must distinguish in playing between 'singing style' and 'playing style', that is, playing Cantabile from one note to another with such perfect union, that one hears no gaps; and on the contrary, 'playing style' must be carried out with some separation from one note to another. To distinguish what is in 'singing style' and what is 'playing style', one should observe those passages that go by step are 'singing style', and consequently are to be played smoothly and without gaps; passages that go by leaps are in 'playing styie', and are to be expressed by detachment.

He gives further advice on recognising the two styles based on the texture of a composition: 
Per conoscere la natura d'un pensiero se dovrà suonarsi allegro, ò andante, osservisi se l'andamento delle Parti sarà eguale alla Principale, segno è, che và allegro, e suonabile; per lo contrario quando le Parti nutte non sono d'andamento equale sarà Cantabile. (196r: 3)

To understand the nature of a [musical] thought, whether it should be played allegro or andante, one may observe whether the movement of the parts is equal to the principal [part], a sign that it is allegro and in 'playing style': on the contrary, when the parts are not all of an equal [rate of] movement, it will be 'singing style'.

It is important, according to Tartini, not to mix up the two types of delivery, so that disorder and illogical playing do not result-in an emphatic paragraph that recalls Frescobaldi's phrase (I6I5) 'otherwise there would be confusion':

Inoltre, come che nei suonare vi sono i suoi sensi, bisogna avvertire di non confondere un senso, con l'altro, onde per evitare questo disordine, e necessario far sentire un poco di vacuo da un senso all'altro, non ostante, che fosse un andamento cantabile (Tartini I77r: ed. Jacobi 196r: 2).

Besides, as in playing there are specific meanings, one must warn against confusing one meaning with another, and to avoid this sort of disorder, it is necessary to make felt a little space from one type of meaning to another, notwithstanding that it was a cantabile passage.

In other words, cantabile passages may appear alongside more virtuosic passages within the same piece, and the performer's task is to recognise them and set them clearly apart from each other.

Tartini also defines different affects within the cantabile style. Some ornaments are inappropriate in the slower, more reflective types of cantabile playing, for example the Mordente (illustrated as a 3 -note turn before the note).

... però il Mordente di sua natura conviene più al Suonabile che al Cantabile; $e$ quando si voglia adattare al Cantabile non conviene ad ogni natura di Cantabile; ma al solo Cantabile Andante, Allegro, e che ricerchi qualche spirito nell'Espressione; non mai al Cantabile grave, sostenuto, e malinconico (Tartini 1771: ed. Jocobi 196r: r7).

But the mordente by its nature suits playing style more than singing style; and when it is desired to adapt it to the singing style, it does not suit every type, but only Cantabile Andante, Allegro, and when one seeks some energy in expression; never Cantabile grave, sostenuto, and melancholy.

The appoggiatura, on the other hand, is most welcome in the singing style.

[Le appoggiature lunghe e sostenute] ... si esprimono con la stessa regola delle Appoggiature lunghe, per Scala discendente, et hanno molto, et ottimo luoco nel Cantabile Sostenuto, Grave, e Patetico (Tartini 177r: ed. Jacobi 196r: 9).

Long sustained appoggiaturas are expressed with the same rule as long appoggiaturas by descending degree, and are often-and best-used in Cantabile Sostenuto, Grave, and to express pathos.

Ornaments such as the trill must be performed within the context of the prevailing style:

Vi sono poi altre infinite adattazioni del Trillo e rispetto al Cantabile, e rispetto al Suonabiie (Tartini 1771: ed. Jacobi 196r: 13).

There are infinite adaptations of the trill with respect to singing style and to the playing style. 
For Tartini, then, teaching the art of performance meant teaching the recognition of styles (or 'modes') of composition, which would in turn enable the performer to select appropriate bow strokes, ornaments, tempo and articulation. It is not possible to demonstrate a direct relationship between Scarlatti and Tartini in terms of contact or training. But Tartini, born only seven years after Scarlatti, puts forward in this treatise a concept of style recognition that matches closely the contrasting style types found in Scarlatti's keyboard pieces. His treatise gives valuable evidence towards forming a sense of Scarlatti's understanding of cantabile within his cultural context.

Domenico Scarlatti's stylistic background may also have included ideas formed on a basis similar to that of Tosi, the Italian singing teacher and writer, who touches on the idea of cantabile in the context of the cadenza. Tosi ( 1723 , trans. Galliard 1742: 53) denounces those who 'deafen the world with many divisions' and goes on to offer-humbly-his idea of good taste:

... che il buon gusto non risiede nella velocità continua d'una voce errante senza guida, e senza fondamento, ma nel cantabile, nella dolcezza del Portamento, nelle Appoggiature, nell'Arte, e nell'Intelligenza de' passi, andando da una nota all'altra con singolari, e inaspettati inganni con rubamento di Tempo, e sul Moto de' basso, che sono le qualità principali indispensabilmente essenzialissime per cantar bene, e che l'umano ingegno non può trovar nelle lore capricciose Cadenze (Tosi 1723: Napoli repr. 1904: 101).

I must say ... that good taste does not consist in a continual velocity of the voice which goes thus rambling on, without a guide, and without foundation; but, rather, in cantabile, in putting forth the voice agreeably, in appoggiaturas, in art, and in the true notion of graces, going from one note to another with singular and unexpected surprises, and stealing the time exactly on the true motion of the bass. These are the principal and indispensable qualities which are most essential to singing well, and which no musical ear can find in your capricious cadences (Tosi z723: Pilkington repr: 53).

If the first 'element of good taste', cantabile, provides a covering term for all the succeeding items on this list, we have here a set of distinct characteristics in which certain ornaments, the use of tempo rubato, and moving from one note to another are predominant. From Tartini, the violinist, we learn that cantabile may be a manner of composing, even involving the invention of his term 'suonabile' to form the contrast; from Tosi, the singer, we read that it is a style of performing that requires great art while dispensing with virtuosity. Both these concepts are helpful when we approach Scarlatti's sonatas marked 'cantabile'.

The following discussion is based on markings in Domenico Scarlatti's Sonatas as they appear in Kenneth Gilbert's Le Pupitre edition (1975-84), which is based primarily on the Venice manuscript collections (abbreviated to V[enice]). The Scarlatti scholar Joel Sheveloff gives the principal argument for considering the readings of this source as relatively reliable, though he points out that the other principal collection, known as Parma $(\mathrm{P})$, would make a preferable basis for an authoritative edition, as 'the closest manuscripts to the lost originals' ... '[T]he main scribe [of $\mathrm{V}]$ seems to have taken great care in writing $P$ and making sure that it followed his source, which we all imagine to have been in Scarlatti's hand' (1985: 429). Although Gilbert does not record all significant variant markings between these two sources, those relevant to this study are given, for example, $\mathrm{K}$. $\mathrm{I} 32$ in which, he points out, only source $V$ gives the marking cantabile. 
As far as chronology is concerned, we are on notoriously shaky ground with the Kirkpatrick numbers for Scarlatti sonatas; the numbers, adopted by Gilbert, are now widely believed to have little connection with the order of composition, let alone with any concept of 'early' and 'late' compositions. Van der Meer (1997) offers a quite different perspective, based on the correlation of ranges of the sonatas with the types of instrument known to be available to Scarlatti, particularly through his association with Queen Maria Barbara of Spain. On the basis of Van der Meer's chronological grouping of the sonatas, it may be stated that Scarlatti's cantabile sonatas cover a period from his early sonatas (i.e. up to 1740 ) to the end of his composing life. In support of the latter claim, we may cite a volume in the Santini Collection, Münster, which carries the heading Ultime Sonate per Cembalo di D. Domenico Scarlatti, composte nell'Anno 1756 and 7757 , in cui mori (Pagano 1985: 458). The existence here of two consecutive pairs of sonatas from his last year, each with the first marked Cantabile (K. 544 and 546), gives telling evidence of Scarlatti's lasting attachment to the cantabile sonata.

To examine Domenico Scarlatti's cantabile style, we may start with one of the most familiar-the A major Sonata, K. 208 (see Example 2). It is a concise but impassioned aria, a mere 25 bars in binary form. The texture is a melodic line and accompanying left hand in crotchets throughout, ranging from single to thicker chords, though rarely more than 2 - or 3-note chords. The spacing of the accompaniment is transparent, sometimes highly dissonant, and always judged with precision against the intervals and tessitura of the slowly unfolding melodic line. Melodicially, the intervallic movement within phrases - after the very first barsis mainly stepwise. The centre of the piece-the first 5 bars of the second section-is intensely chromatic, with syncopations becoming prominent in the melodic line. Here Scarlatti delays the right hand resolution on the first and third beats to draw attention to the tension between a generally predictable bass part in a cadential context, and the chromatic displacements in the melodic line. The chromaticism dissolves in time for the cadence, but only just in time, on the final bar of each section.

The cadential trill of the final section (bar 25) exhibits an approaching flourish to the preceding beat, with the notation suggesting an acceleration of the ornamentation towards the trill. In the first section, the cadential approach is made with a famous harmonic/dynamic gesture, often quoted as an example of the Scarlatti family's predilection for chords on the dominant that include both 5 th and unresolved $4^{\text {th }}$ in the left hand, while the right hand carries the $5^{\text {th }}$ and the major 3 rd of the chord.

Another apparently early piece, K. 144 in G major, shows similar characteristics throughout its 34 bars. The melodic line, played always by the right hand, moves predominantly by tones and semitones, expanding to some larger intervals in the second section - an octave or minor ninth between phrases. Within phrases, it is the stepwise movement that prevails. The left hand consists of crotchet movement, as opposed to the semiquavers of the right hand, and starts in single notes above middle $\mathrm{C}$. By bar II, the single note crotchets are thickened to $3^{-}$and $4^{\text {-note }}$ chords, a feature maintained in the second section, though here 3 -note spacings prevail. So far, these points conform exactly to Tartini's account of the term cantabile, in terms of both melodic intervals, and rhythmic motion and texture (quando le Parti tutte non sono d'andamento eguale sarà Cantabile). 
K. 208

Adagio e cancabile
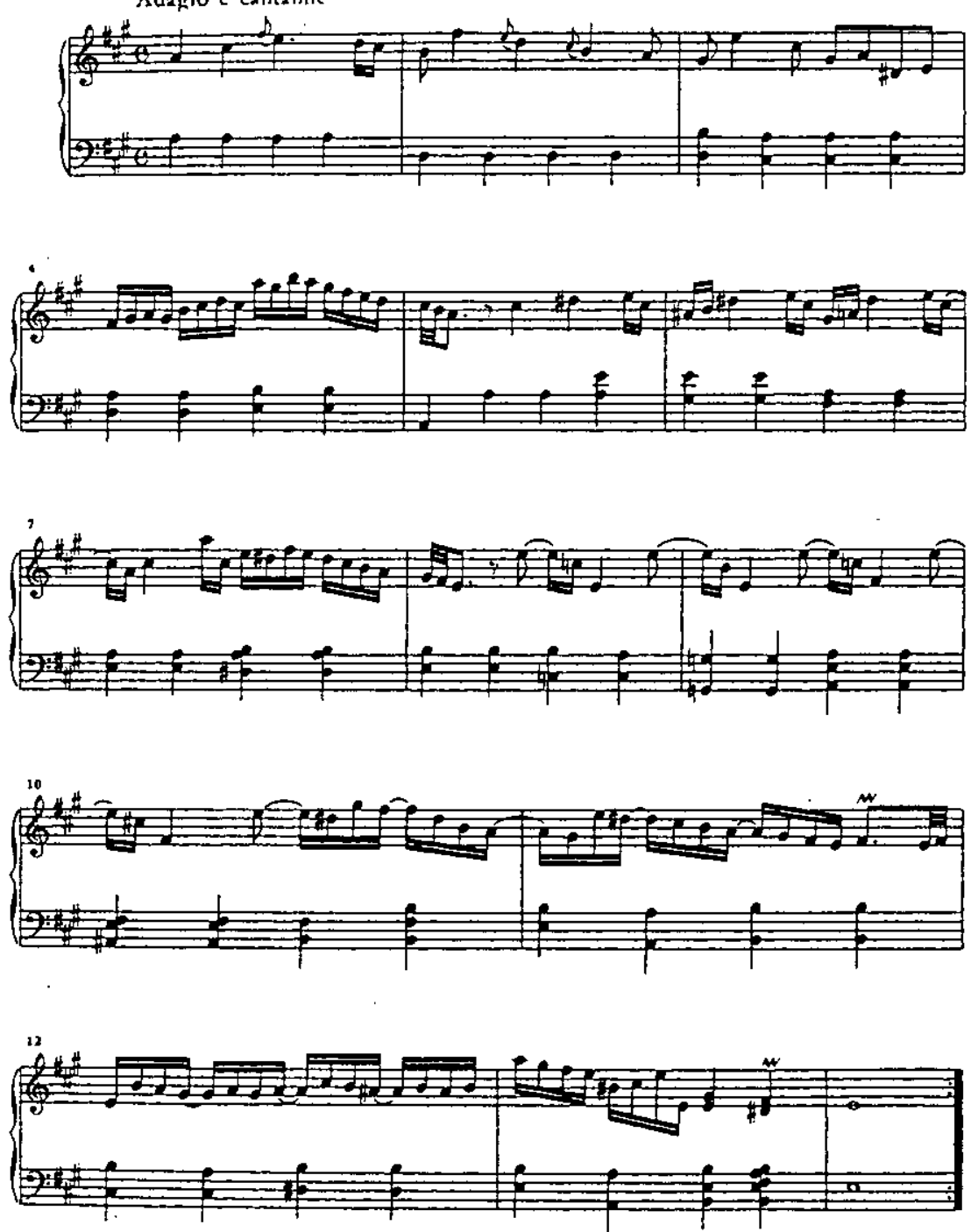

Example 2 D. Scarlatti, K. 208

Source: Le Pupitre edition, vol. III.

At least four further features of K. I44 demand attention. Harmonically, the music moves from and returns to a very diatonic language, via passages of sinuously chromatic phrases, climaxing in the first beat of bar 27 . Here, the 7 th chord on $\mathrm{E}$ flat, with added 6th in the melodic line, gives the most distant spacing between right hand and accompaniment in the piece, as well as the highest melodic note, and the most dissonant moment in terms of harmonic direction (the sudden appearance of $\mathrm{C}$ minor in the accompaniment) and the vertical crunch of $c^{\prime \prime}-\mathrm{d}$ ' $E$ flat, with $F$ sharp added already by the second semiquaver of the beat. Melodically, a high degree of chromaticism is present, from the diminished 7 ths 

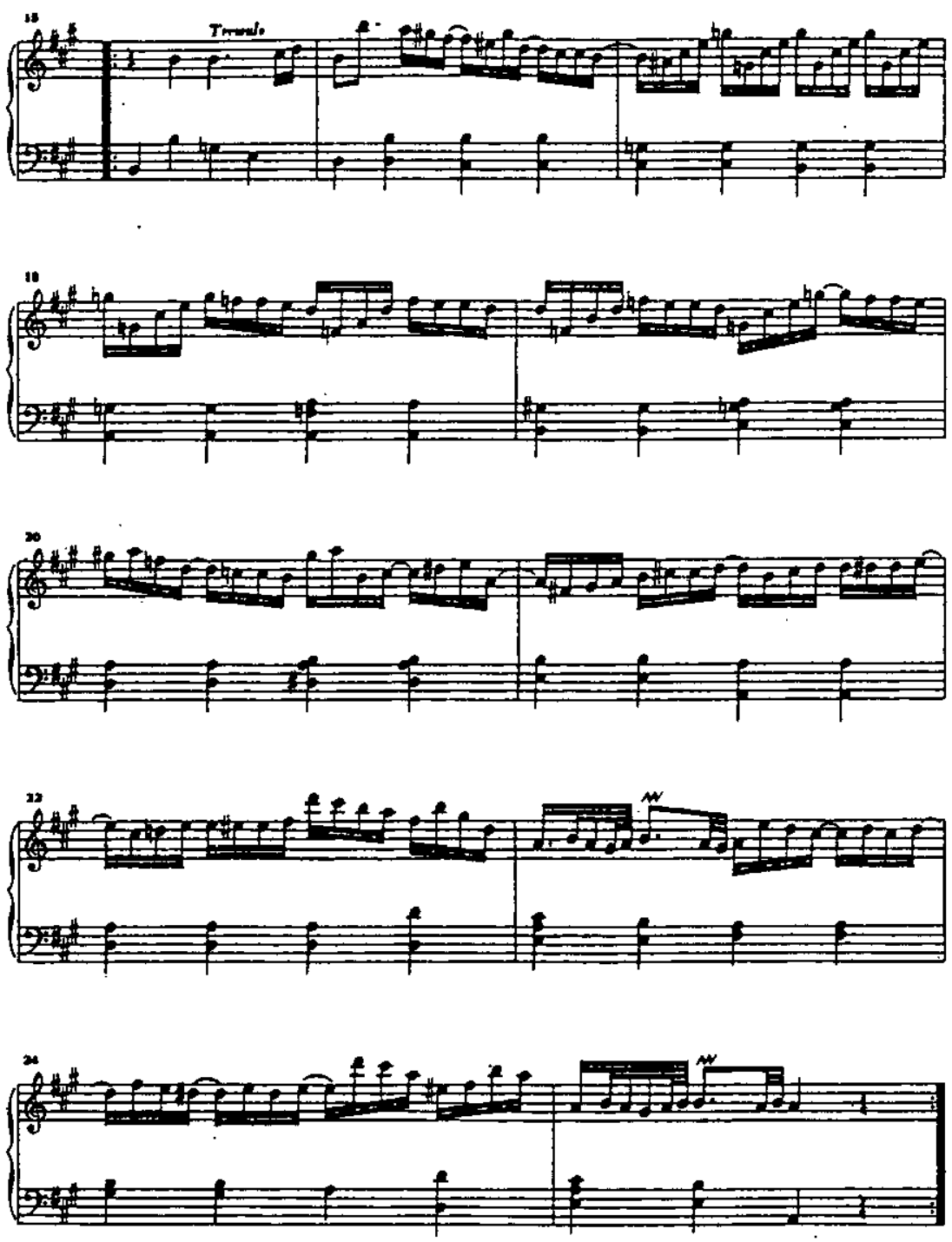

outlined in the first section (bars 10-II) to the augmented ands of the second section (bars 22-3) to the semitone movement and recurrent appoggiaturas that frequently displace the principal melodic note from the beat (e.g. bar 23 , beat $\mathrm{r}$; bar 25 , beats I and 3; bar 26, beat 3; bar 30, beat 3 ).

Finally, a rhythmic point. As the piece progresses, we find an increasing incidence of displaced melodic notes, signalled by notes tied over the barline, or between beats. This feature first appears in the first section, between the last right hand note of bar Io and bar II, where it is pervasive; in the second section, it figures in particular areas - bar 27 , beats $2-3$ following the climactic moment of the 
piece (see Example 2), and then bar 28, beat 4 to beat I bar 29. This longer tied note-crotchet to quaver, rather than quaver to semiquaver-gives the balancing moment of repose to the harmonic 'distress' of bar 27 , beat $\mathrm{I}$, and resolves, or indeed, contradicts, its $\mathrm{C}$ minor inflection by confirming $\mathrm{C}$ major with the $\mathrm{E}$ natural taking the longest melodic duration of the piece. Two further tied notes (bars $29-30$ and 30-I) continue the pattern quaver-quaver/tied quaver/semiquaver from beat 4 to following beat.

The final 3 bars return with their cadential formulae to the more straightforward melodic/rhythmic/textural patterns of the opening. The cadential trills that conclude each section of K. 144 (bar 17 , beats $3-4$ and bar 34 , beats $\mathrm{I}-2$ ) show in each case a complex approach to the trill itself. Consisting of a kind of lower turn, this moves into an anticipation of the trill, though from the lower note: an effect
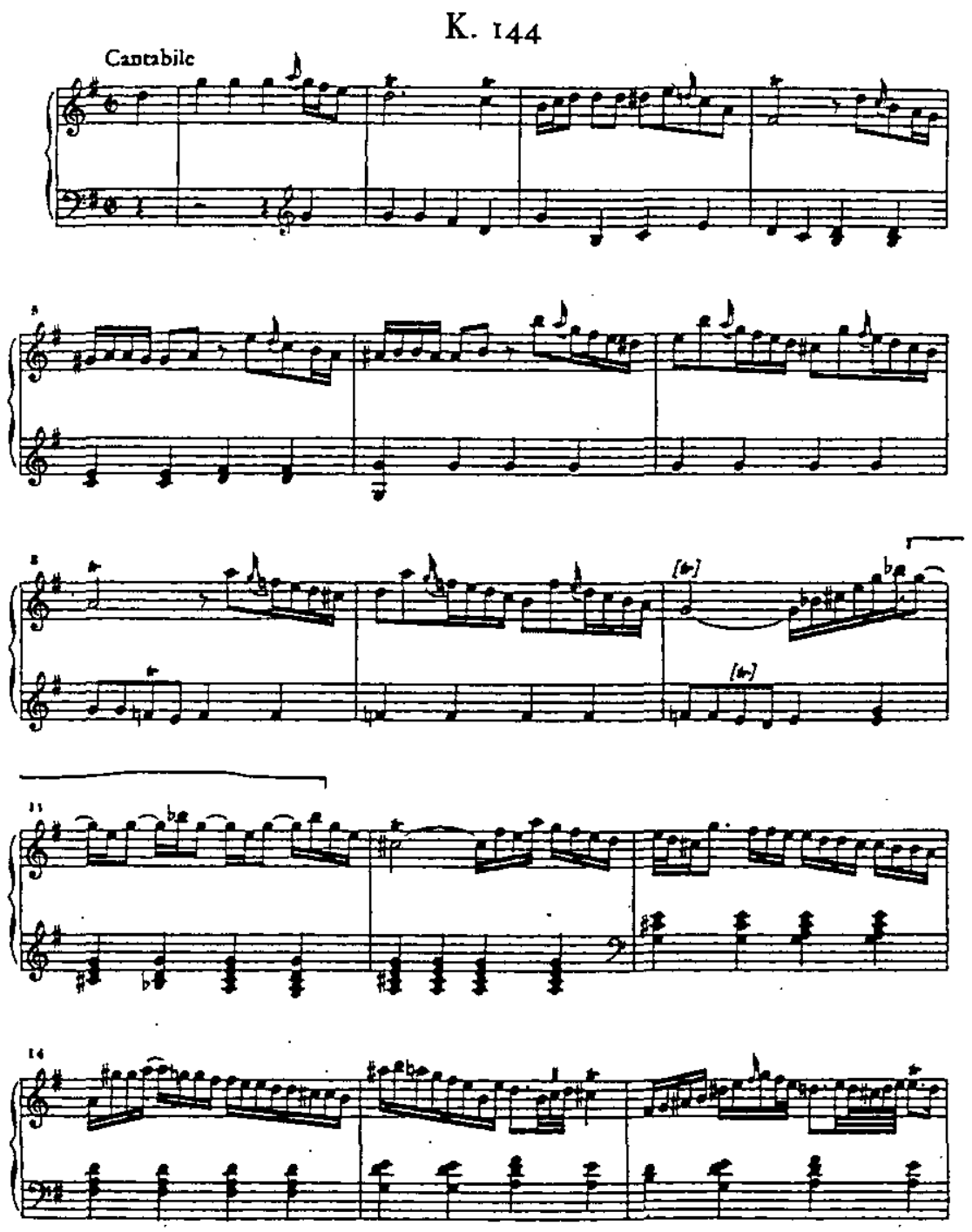

Example 3 [attrib.] D. Scarlatti, K. 144

Source: Le Pupitre edition, vol. III. 
rather like seeing a type of controlled spin in an ice-skating routine accelerate into a rapid spin on one spot.

Sheveloff (1985, 1986: 418 ) has thrown doubt on the attribution of K. I44 to Scarlatti, on stylistic as well as textual grounds, suggesting the Spanish composer Sebastian Albero as a possible alternative. However, the sonata shares with K. 208 a number of elements that seem fundamental to the meaning of the term cantabile as used by Scarlatti. These include the use of aria style, consisting of a 'solo' melodic line and accompaniment; a melodic line with predominant stepwise movement; considerable tension developing within the piece between melodic line and accompaniment, through rich chromatic inflections; a structure that moves from clearly voiced diatonic progressions and harmonies to phrases of extreme chromatic inten-
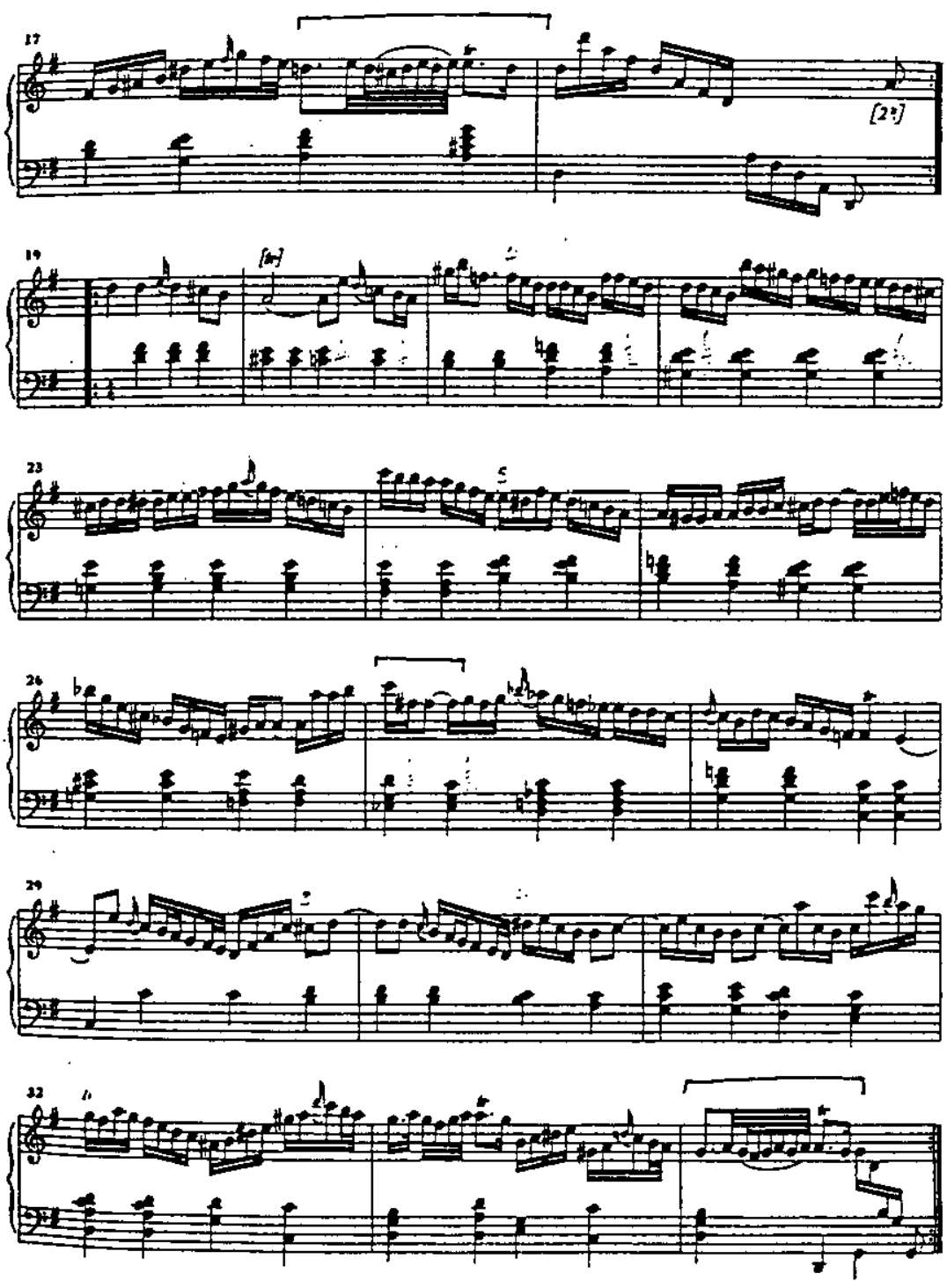

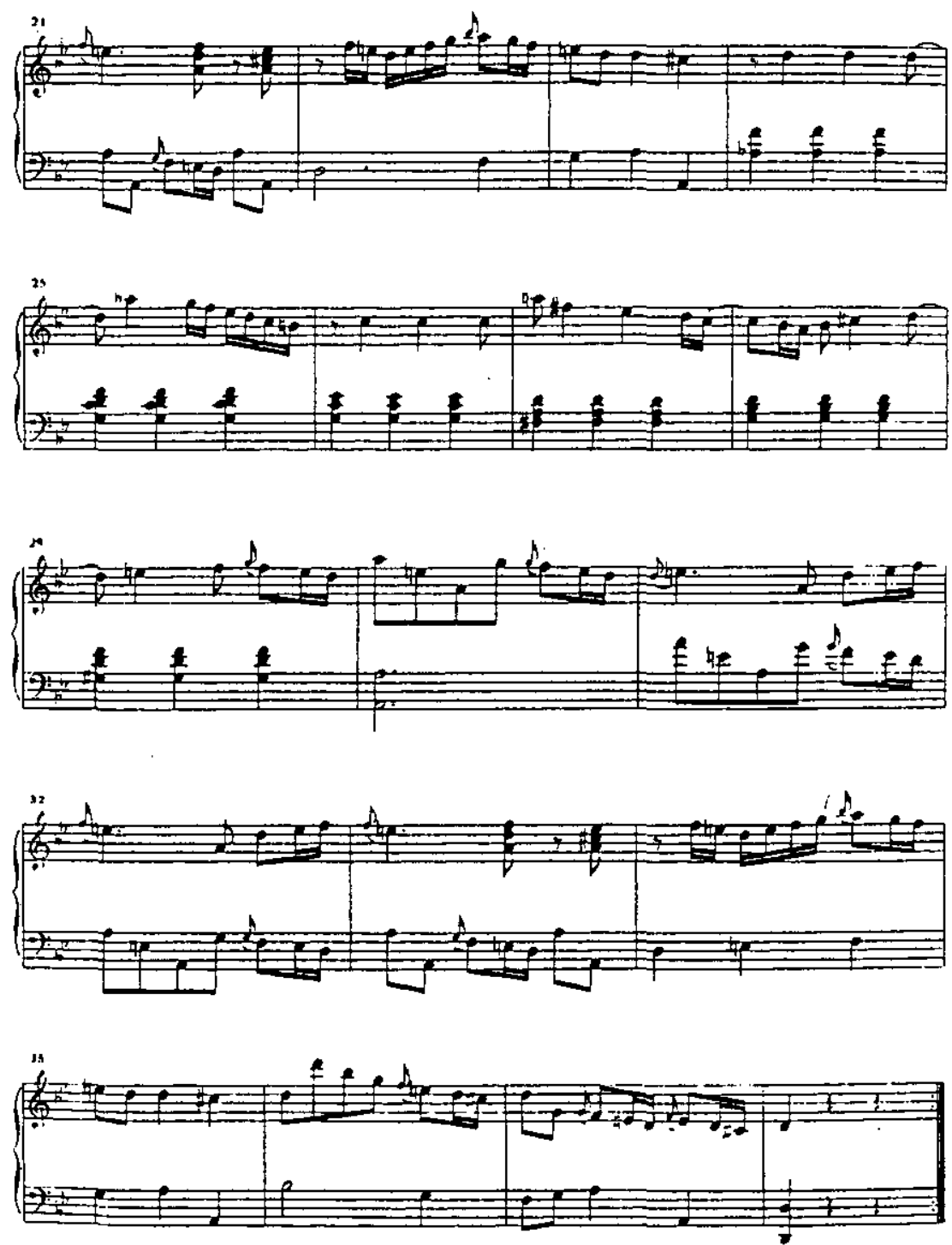

Example 4 D. Scarlatti, K. 234, bars 22-30 and 6I-9

Source: Le Pupitre edition, vol. V.

sity, and back; tied notes displacing the melodic line from main beats at significant points in the piece; and finally, a way of notating ornamentation that shows an unusual degree of detail, specifically with its extravagant preparation of the cadential trill.

K. 208 is one of the most frequently studied of Scarlatti's sonatas-thanks mainly to its inclusion in volume I of the Kirkpatrick/Schirmer Sixty Sonatas by Domenico Scarlatti-but its cantabile style remains a mystery to many keyboard players, to whom it might come as a surprise to find how frequently Scarlatti was to use the designation cantabile in his compositions. Making the assumption that 'cantabile' was for Scarlatti as much a style of composition as a style of perfor- 

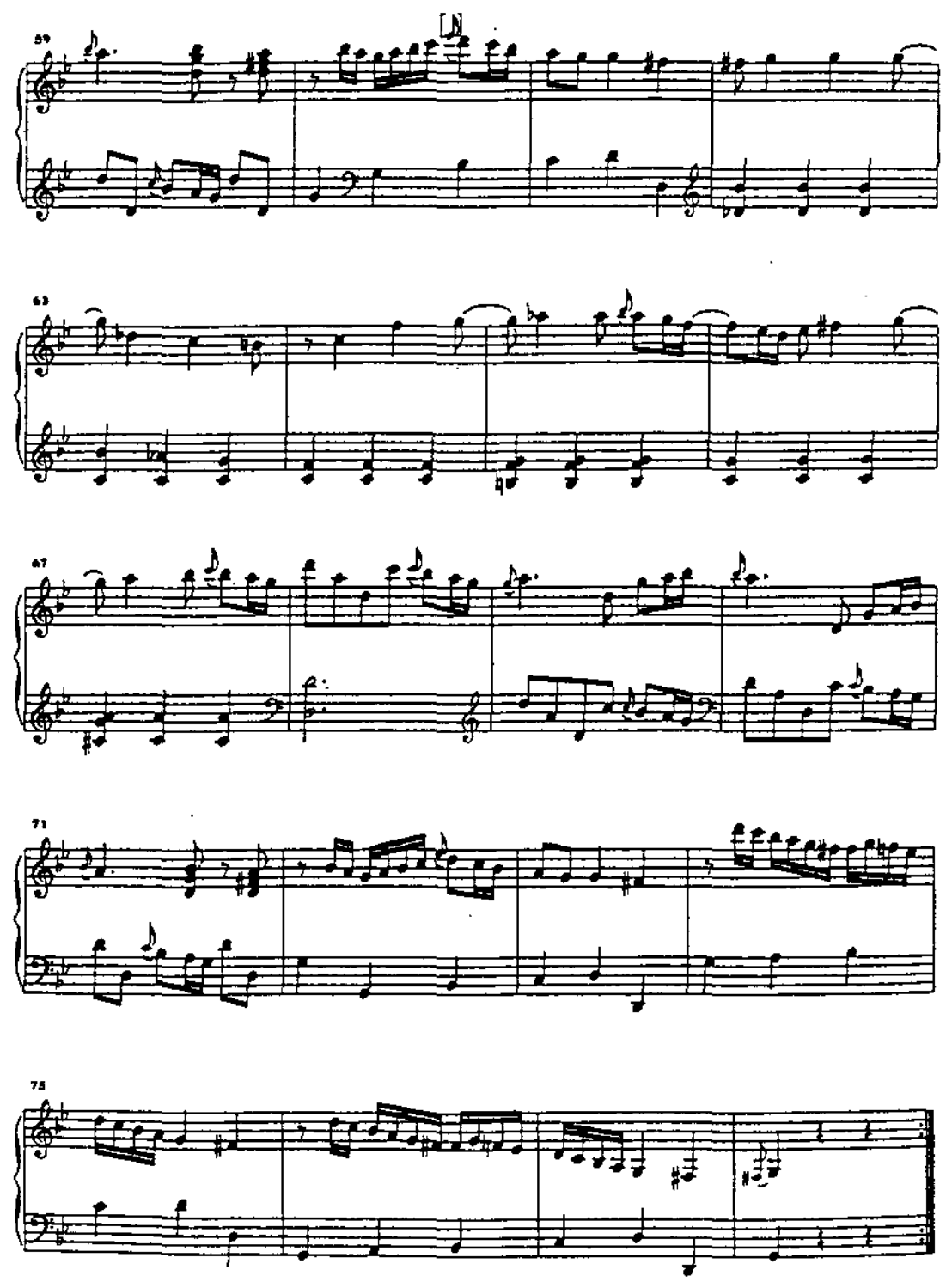

mance, I suggest that the search for this compositional style may bring with it some fresh insights that will help to capture the spirit of cantabile and thus avoid that confusion of genres or sensi of which Tartini speaks.

It seems that K. 208 is the only sonata of the Venice manuscript volumes III and IV to carry the marking cantabile, making it a special type of piece in its avoidance of Scarlatti's habitual 2-part counterpoint and wide-ranging tessitura and modulations with leaping intervals in both hands. By contrast, the equally well-known Allegro K. 209 that follows the intensely considered tranquility of K. 208 explodes with energy, showing the hallmarks of Tartini's 'suonabile' style: leaps suggesting 
detached articulation, and an equal rate of movement between the two parts (i.e. imitative counterpoint).

Only occasionally does any of the sonatas marked Andante exhibit the cantabile style characteristics. K. 234 in G minor (Venice, III, 29) is a case in point (see Example 4). Though it begins with two bars of imitative chordal texture between the two hands, it embarks on two notable passages of sinuous melodic line and chordal accompaniment. The first of these sets up the modulation to the second key area (D minor, v); the second occupies bars $24-9$ of the 38-bar long first section, and has a fully syncopated melodic line against a richly voiced chordal left hand. Here the chromatic detail of each hand creates a complex centre to the section, which then dissolves into the imitative lines of the opening, now based on bare fifths.

Scarlatti reinterprets this section at bars $62-7$. As in the first section, this passage opens again on its momentarily puzzling and intensely dissonant cadential resolution. Instead of resolving to the tonic (now $G$ ), the bass slips down a semitone, initiating a sequence in which the bass part falls successively by semitones. At the same time, an appoggiatura in the melodic line displaces the tonic from the main beat, leading to the vertical clash of F sharp" against B flat/ D flat as bass. It is a moment that contrasts powerfully with the straightforward diatonic language of the immediately preceding section, a moment difficult for the listener to unscramble. The incomprehensible dissonance sets up a passage in which constant displacement of the first beat of the bar seems to spin out the chromatic manoeuvring of both melody and accompaniment, not allowing any break in phrasing. Finally, the chromaticism dissolves to a further imitative texture, with bare fifths now predominant. Possibly, this too is a piece that could have received the designation cantabile, but for the andamento eguale of its opening.

The 'cantabile' indication occurs most frequently in the sonatas grouped together as volumes $X$ and $X I$ by Kenneth Gilbert in the Le Pupitre edition: the two volumes reflect the grouping of the later volumes of both Parma and Venice manuscripts. Compared with the single piece K. 208 marked Adagio e cantabile in Venice volumes III and IV, we find three in Venice, XI, three in Venice XII, one in Venice XIII, and two in Parma XV. This makes a total of Io out of the last 96 sonatas of Kirkpatrick's numbering that carry the marking cantabile either alone or together with Andante or Adagio. 'Andante e cantabile' becomes a favourite marking in these final volumes: it appears in five out of these ten sonatas.

This increased incidence of the cantabile indication suggests several possible developments. If the markings do derive from the composer's manuscriptshypothesis that almost certainly cannot be checked, owing to the absence of any autograph manuscripts of Domenico Scarlatti-we are looking at the first recorded instances, to any significant extent, of cantabile as a performance direction for whole pieces. Yet if the markings do not always derive from the composer, but were sometimes supplied by the copyists of the respective manuscripts, they are of equal interest: in this case, we would be dealing with the stylistic recognition by copyists of a certain type of slow tempo sonata by Scarlatti.

At least one work, the well-known K. 132 (C major) gives an example of divergent tempo markings in the two manuscripts, Venice and Parma. Only the Venice manuscript has the marking 'Cantabile', while the Parma marking is the simpler 'Andante'. How frequently did the copyist(s) of Venice change-up-grade-the marking from a simple tempo indication to one with the more 'expressive' conno- 
tation? From the critical notes of Gilbert, K. 132 would seem to be the only sonata to show such a difference. But the marking need not be regarded as inappropriate. Possibly the copyist of the Venice manuscript recognised the cantabile features and deliberately changed the marking.

Certainly K. I32 (see Example 5) contains many of the features noted in K. 208 and K. I44: the aria-style texture, consisting of a 'solo' melodic line and accompaniment (e.g. bars $25-32,61-72$ ); a melodic line in which stepwise movement is predominant $(25-32,39-48$ and $61-4)$; chromatic twists in the melodic line, realised through an exceptional degree of dissonance between melodic appoggiaturas and thickly voiced accompanying chords (e.g. bars $25-8,6 \mathrm{I}-8$ ); a structure that moves from clearly voiced diatonic progressions and harmonies to phrases of extreme chromatic intensity, and back to diatonicism; tied notes displacing the melodic line from main beats at significant points in the piece (bars $53-7$, preceding the 'recapitulation' in the tonic minor); and ornamentation notated with unusual detail, specifically with its voluptuous preparation of the cadential trill (bars 30 and 68). Even the appearance (only in source P) of the term tremulo (see Sachs, 1991) in the diatonic cadential areas, bars $29-32 ; 69-72$ ) suggests the style of K. 208.

\section{Cantabile as a tempo indication}

In Clive Brown's (1999) exhaustive study of performance markings and meanings, the term cantabile does not get an entry in the index, but it does receive a page at the conclusion of chapter 10, 'Tempo Terms', under the subsection, 'Other terms affecting tempos'. Brown suggests that " cantabile" was employed as a tempo direction in its own right, as a modifier of tempo' (1999: 374). Because of his classification of the term under the general heading of tempo, Brown looks for tempo types associated with the marking, drawing attention to the predominance of slow tempo markings. For example, he points to Mozart's use of Andante cantabile, suggesting it indicates a slower tempo than the unqualified Andante. Yet Scarlatti's designation Adagio [or Andante] e cantabile in, for example, K. 208 and K. $48 \mathrm{I}$, gives the impression that cantabile is not necessarily a part of the tempo itself, but more a way of describing the delivery of the melodic line, or the relationship between the melodic line and its accompaniment.

From the point of view of Domenico Scarlatti's sonatas, the most interesting idea put forward by Brown appears in his statement that '[a]ccording to some English writers, "cantabile" could also have a more specialised meaning in the late eighteenth century and early nineteenth century'. Did this meaning refer to something other than choice of tempo? Brown quotes eighteenth-century writers, Anselm Bayley (1771), Charles Dibdin (Music Epitomized), and the author of an anonymous harpsichord treatise (c. 1790) who all suggest that, for these musicians, 'cantabile' was a style of expression-maybe exaggerated expression, or even, a type of cadenza. In both cases, the element of improvisation is a predominant part of the definition, if it is regarded with favour: 'the introduction of extempore ideas gracefully' (Dibdin), or with disapproval and mockery: 'What are called cantabiles betray in general such a want of invention, and absurdity of application, that they make the hearer sick before they are half finished' (Bayley, p. 65, quoted in Brown, 1999: 374).

There may be significance in these comments for Scarlatti's cantabile style: it was in England that a circle of his admirers flourished with particular intensity (see, for example, Richard Newton 1939); it was in England that Clementi was to 

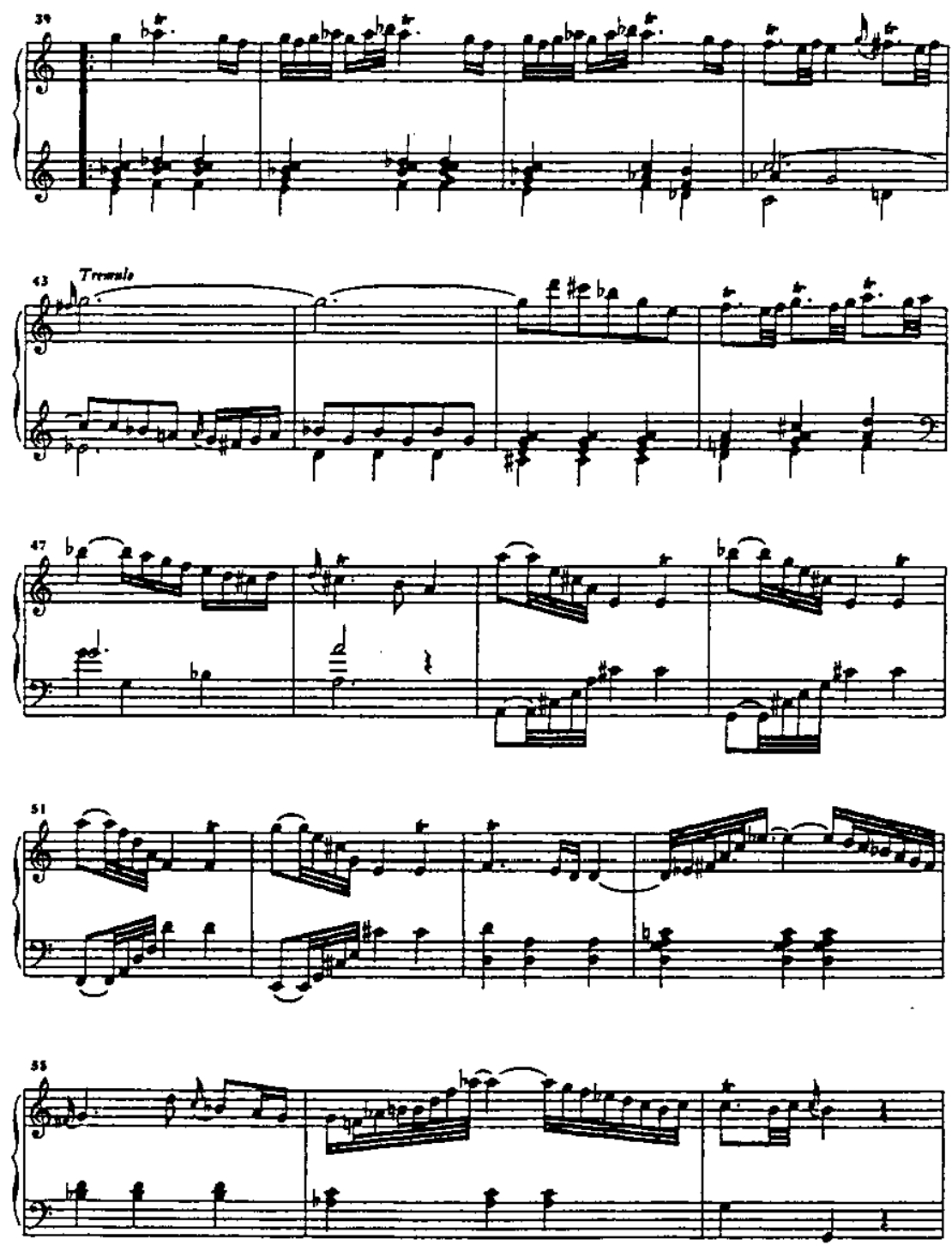

Example 5 D. Scarlatti, K. 132, bars 53-72

Source: Le Pupitre edition, vol. III.

publish his collections of Scarlatti's sonatas, bowdlerised maybe, but putting forward the composer's work at a time when it was hardly known elsewhere; it was in England that awareness of Scarlatti's music survived his death. It may not be too far-fetched, thus, to imagine that Scarlatti's music had some impact on these English definitions of the term.

If cantabile means more than the aspect of tempo in Scarlatti's sonatas, we need to ask what elements he may have understood as being 'like singing'. To today's musician, projection of tone would be the most obvious characteristic, a density of tone capable of lifting the melodic line well into the foreground. The associated marking 'Sostenuto' seems not to appear with any regularity in the eighteenth cen- 

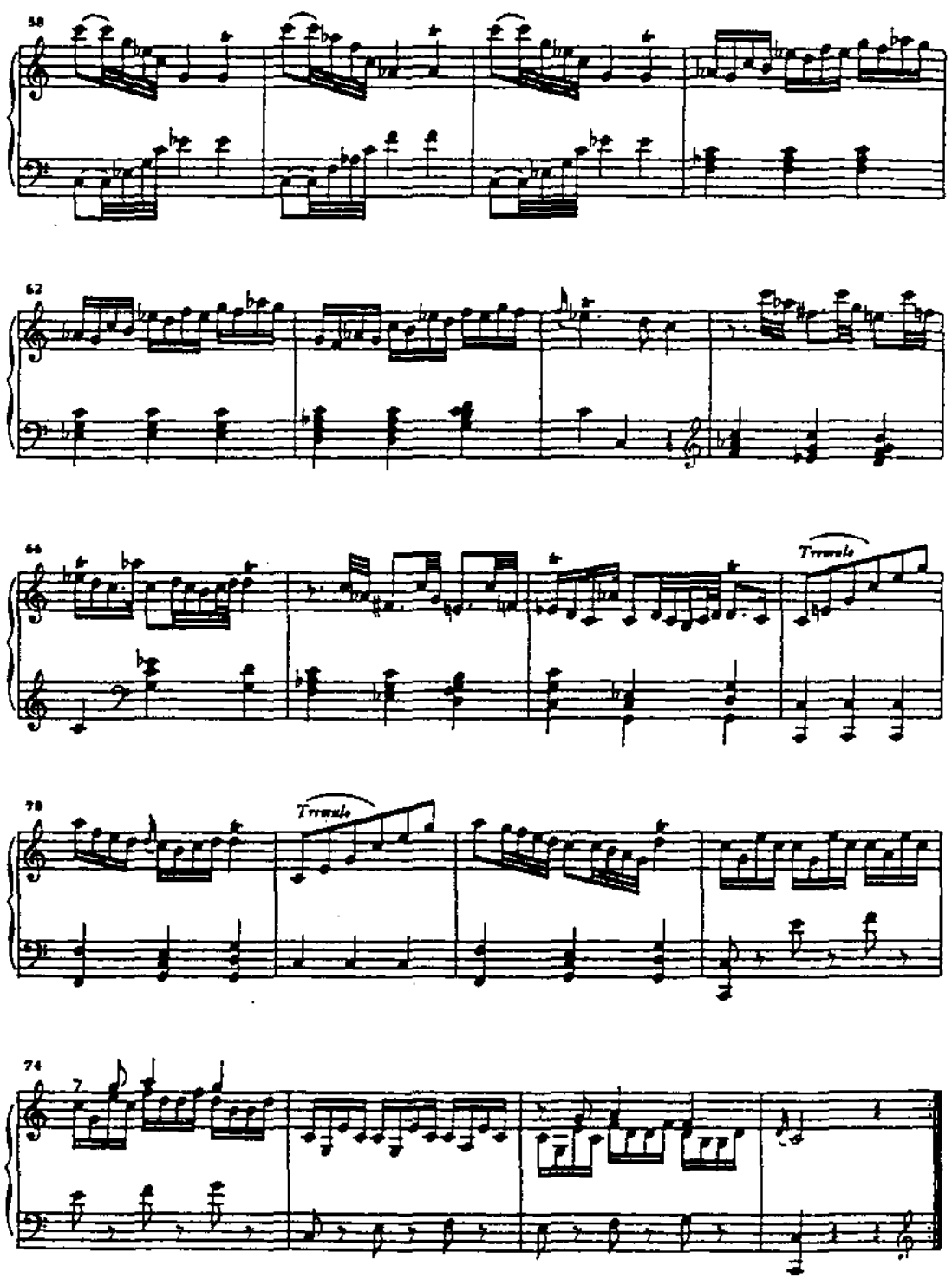

tury, maybe not until the time of Beethoven. Although today we tend to equate the two terms, the sound ideal expressed by sostenuto belongs, perhaps, to a different aesthetic world from the eighteenth-century cantabile, one that demands longer sounds than those usually produced in the articulated speech of eighteenth-century music. If a vocal line was swamped by accompanying instruments, there was the ever-present instruction, taught within the Scarlatti family, to play piano when the voice entered. Alessandro Scarlatti's instructions in his letter of 1706 to Ferdinando di Medici (Fabbri, 196r: 73-4) and markings in his scores show clearly the importance placed by the head of the Scarlatti family on an instrumental accompaniment that did not compete with the voice for attention. 
The legato described by Tosi in his Essay on Singing, the 'putting forth of the voice' (as Galliard translated 'portamento') was equally part of the singer's province that Domenico Scarlatti presumably aimed to portray on the keyboard. Joseph Kerman in his Concerto Conversations addresses the question of what singing meant to the eighteenth century instrumentalist:

In Handel's time, and in Mozart's, imitating human song meant imitating the ornaments and graces the singers regularly applied to melody lines that were notated in
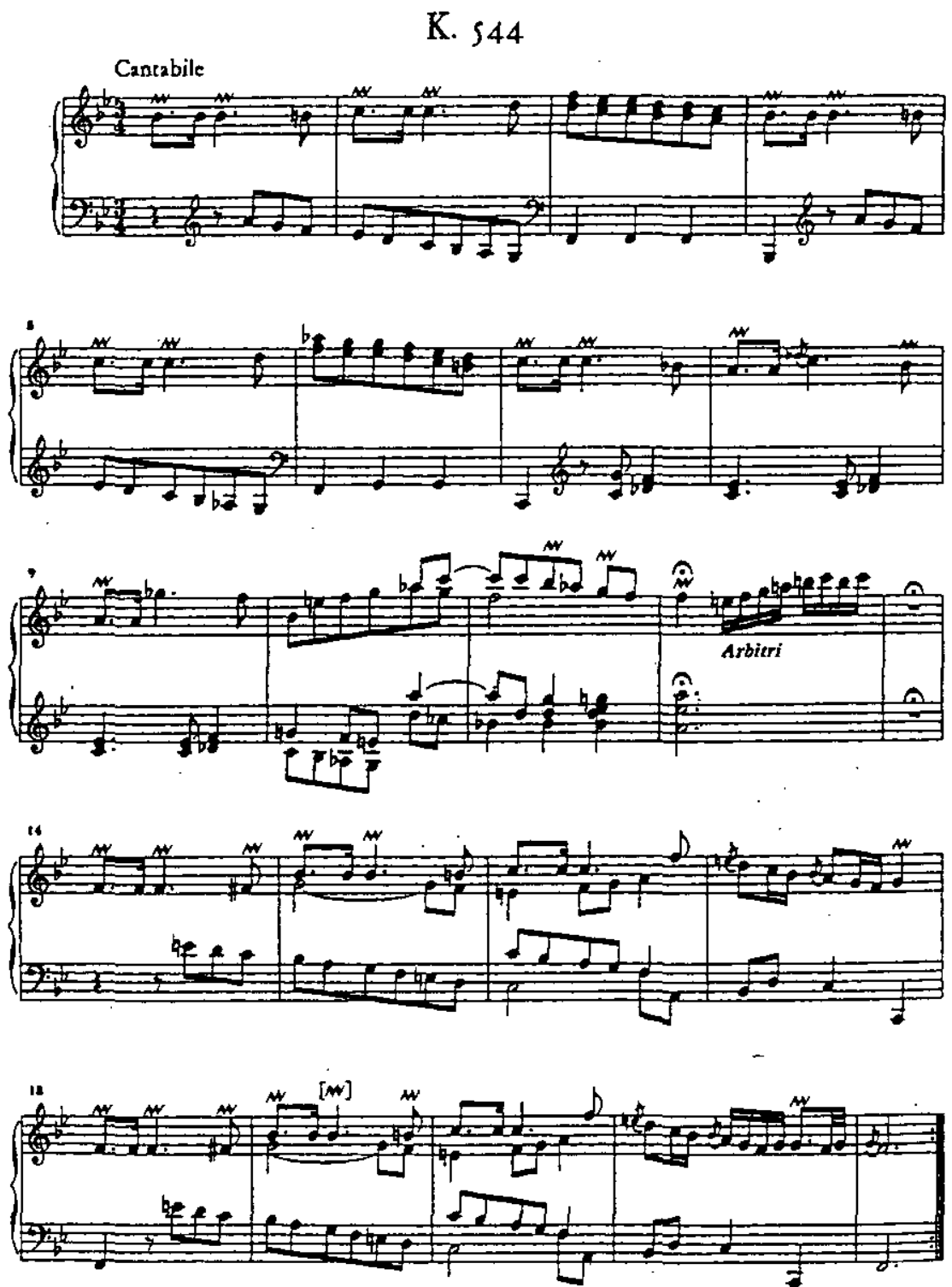

Example 6 D. Scarlatti, K. 544 , bars $7^{-15}$

Source: Le Pupitre edition, vol. XI. 
a skeletal form, in a sort of shorthand. Embellishment is surely essential-or anyhow, something has to be done-in order to maintain the illusion that a keyboard instrument can sing (Kerman 1999: 69)

Trills approached with fluidity, cadenzas, the ornament of tempo rubato with its desynchronisation of vocal line from accompaniment-of right from left handthese are qualities of the eighteenth century singer that Scarlatti was able to translate into keyboard terms. The singer could also be expected to hold up the meter, as Scarlatti does in K. 544, where a momentary cadenza-like passage on the dominant is approached via an augmented 6th chord, marked 'ad'arbitrio'- a marking more commonly seen in aria manuscripts of the period (see Example 6). Some keys are favoured, other keys are neglected by Scarlatti, in the Cantabile sonatas (see Table I). C major has three pieces, and D major four, marked with some variant of cantabile, while their relative minors, $A$ minor and $B$ minor, have none. In $A$ major there are two sonatas, in $F$ sharp minor, there are none. Further afield in the sharp keys, derivative of the hard hexachord, there are no Cantabile pieces either. ${ }^{1}$ Of the soft hexachord keys, $E$ flat and $B$ flat have one and two pieces

Table I Keys of sonatas by Domenico Scarlarti marked Cantabile

\begin{tabular}{|c|c|c|}
\hline $\begin{array}{l}\text { G major } \\
\text {-K I44 [Albero?] } \\
\text { Cantabile K. } 304 \\
\text { Andante cantabile }\end{array}$ & $\begin{array}{l}\mathrm{C} \text { major } \\
\cdot \mathrm{K} .132 \\
\text { Cantabile (V. only) } \\
\cdot \mathrm{K} .170 \\
\text { Andante moderato e } \\
\text { cantabile } \\
\cdot \mathrm{K} .308 \\
\mathrm{C} \text { antabile } \\
\cdot \mathrm{K} .485 \\
\text { Andante e cantabile }\end{array}$ & $\begin{array}{l}\text { F major } \\
\text { NIL }\end{array}$ \\
\hline $\begin{array}{l}\text { E minor } \\
\mathrm{Nil}\end{array}$ & $\begin{array}{l}\text { A minor } \\
\text { Nil }\end{array}$ & $\begin{array}{l}\text { D minor } \\
\cdot \text { K. } 7^{2} \\
\text { Moderato e cantabile } \\
\cdot \text { K. } 17^{6} \\
\text { Cantabile andante }\end{array}$ \\
\hline $\begin{array}{l}\text { G minor } \\
\cdot \mathrm{K} .347 \\
\text { Moderato e cantabile } \\
\text {-K. } 546 \\
\text { Cantabile }\end{array}$ & $\begin{array}{l}\mathrm{C}_{\text {minor }} \\
\mathrm{Nil}\end{array}$ & $\begin{array}{l}\text { F minor } \\
\cdot \mathrm{K} .48 \mathrm{i} \\
\text { Andante e cantabile }\end{array}$ \\
\hline $\begin{array}{l}\text { A major } \\
\text {-K. } 208 \\
\text { Adagio e cantabile } \\
\text {-K. } 536 \\
\text { Cantabile }\end{array}$ & $\begin{array}{l}\text { D major } \\
\cdot \text { K. } 277 \\
\text { Cantabile andantino } \\
\text {-K. } 478 \\
\text { Andante e cantabile } \\
\text {-K. } 490 \\
\text { Cantabile } \\
\text {-K. } 534 \\
\text { Cantabile }\end{array}$ & $\begin{array}{l}\text { E major } \\
\text { Nil }\end{array}$ \\
\hline $\begin{array}{l}\text { Fi minor } \\
\mathrm{Nil}\end{array}$ & $\begin{array}{l}\text { B minor } \\
\text { Nil }\end{array}$ & $\begin{array}{l}\text { Ci minor } \\
\mathrm{Nil}\end{array}$ \\
\hline
\end{tabular}

1. As Chafe (1992: 25) explains: "In the first half of the seventeenth century most individual compositions were normally written in one of the two signatures-that is in either cantus mollis (centred on the $F$ hexachord or one-flat system) or cantus durus (the $G$ hexachord or one-sharp system)'. 
respectively; $\mathrm{G}$ minor has two, $\mathrm{C}$ minor none, and in $\mathrm{F}$ minor we find one of the most beautiful and poignant pieces of this type, K. 482, Andante e cantabile.

\section{Tempo-affect relationships between paired sonatas}

Almost every writer on Scarlatti gives a viewpoint on the possible relationships between the sonatas, and every performer of his music necessarily puts forward a theory through the choice and ordering of pieces $\mathrm{s} /$ he performs. In the case of the Cantabile pieces listed above, an interesting set of relationships may be observed. Three main ways of juxtaposing pieces in different tempi and meter emerge.

Firstly, the Cantabile sonata may be directly linked to the following piece without reaching a full close, or by an overlap of the previous tempo into the next one. The main examples are K. 72 (D minor) in which the capricious Moderato e cantabile moves straight into a Menuet in 3/8; K. I70 (a), with its Andante moderato e cantabile tumbling into a 3/8 Allegro; and two extreme examples K.I76 (d), whose Cantabile andante alternates with a major mode Allegrissimo in $3 / 8$, and ends up in this guise, though the first section ends 'Cantabile come prima'. Here the contrasting meters, tempi and tonalities are interwoven throughout the one sonata. Finally in K. 347 , another capricious Moderato e cantabile attains no repose at all but rushes headlong into the following piece--3/4 Prestissimo. The overlap is carefully shown by the copyist in both Venice and Parma sources with a hand pointing to the final bar, and linking it to the furst bar of the Prestissimo with the instruction 'Al Cader dell'ultimo termino di questa Sonata [i.e. on the second time through], atacca subito la seguente, come avisa la Mano'. The $\mathrm{G}$ minor piece, with its occasional silences and not quite perfect chromatic scales makes a sultry prelude to the incessant chattering of the following $G$ major piece which explodes out of the final cadence of the Moderato e Cantabile.

Secondly, the 'dyptich' or paired relationship seems to have been the most frequently used design by Scarlatti, in which two sonatas of the same key (or sometimes with tonic minor-major relationship) are apparently paired by key similarity and tempo contrast. As Kirkpatrick points out, the copyists of $\mathrm{P}$ and $\mathrm{V}$ present many of the sonatas in this type of sequence. K. 208 and K. 209 make up one of the best known of such pairs, featuring uniquely the marking Adagio e cantabile. Of the last group of pieces, K. 544 (B flat, 3/4) makes a Cantabile 'prelude' to the following Prestissimo, whereas $\mathrm{K} .546 \rightarrow 7$ (g in $3 / 8 ; \mathrm{G}$ ) again shows the minor-major relationship observed between K. 347 and 348 . Indeed, K. $347^{-8}$ is really a 'dyptich' with an overlapping final cadence shared by the two pieces. Remaining pairs in this class are: K. 308 and 309 (C), K. 485 and 486 (E flat), K. 132 and 233 (C); K. 536-7 (A); K. 534-5 (D) K. 507-8 (E flat).

Thirdly, there are pieces in the form of a 'tryptich' (Kirkpatrick's term), that is, a group of three sonatas in the same key with an 'ascending' range of tempi and meters to match. Two groups of D major sonatas are notable examples: K. $47^{8-9}$ and 480 move from Andante e cantabile (3/4), through Allegrissimo (C) to Presto (C); and there is the frequently performed group K. 490-2, consisting of Cantabile (C), Allegro (3/4), and Presto (3/4). The set of F minor pieces K. 48I-3 plot a similar course through Andante e cantabile (C); Allegrissimo (Alla breve); Presto (3/8). In general, the pieces that follow a Cantabile are marked at the quicker end of Allegro. Prestissimo (3/4) follows the leisurely galanterie of K. 536's Cantabile; 
the marking occurs 3 times in the pair in conjunction with a Cantabile piece. Presto also occurs three times, within either a 'tryptich' or a 'dyptich'. Allegrissimo, a favourite marking of Domenico's father in his later years, also appears 3 times in this context.

The pairing or matching of a cantabile movement to a livelier piece in the same key seems to be such a recurrent feature of Scarlatti's pieces in this style, that it may provide in itself a basis for questioning the authorship of K. 144, which stands alone. In general, the conjunction of slow and fast pieces in the Cantabile genre seems for Scarlatti to be a maximising of contrasts. The cantabile acts as a kind of decoy, setting up a mood of deceptive calm with its seductive chromaticism and fragile rhythmic contours. Suddenly with the Allegro/Presto we enter a new world: meandering phrases are replaced by purposeful balanced constructions; leisurely tempo by an alert pace and regular accents; minor tonality by major, in some cases; the intimate tone of singer and accompanist melts into the public spectacle of bravura. Of course these contrasts are present in any performance of consecutively grouped sonatas by Scarlatti. But the contrasts between the Cantabile pieces and their companion sonatas Allegro/Allegrissimo/Presto/Prestissimo are particularly pronounced.

It is possible that a model for this idea comes from Domenico's father Alessandro, in whose toccatas we find an early example of a keyboard cantabile. A Neapolitan manuscript of his toccatas (Alvini (ed.) I98I) contains a massively constructed Toccata (7a) in D minor, with a passage marked 'Cantabile, ed appogiato' [sic] (see Example 7). This acts as a prelude to the Folia moderato, the climax of the work. Beginning with a short passage in recitative style, reminiscent of an earlier Adagio section, Alessandro then embarks on a sustained passage of uniform chordal motion in quavers, accompanied by a left-hand accompaniment marked 'arpeggio'.

Presumably the term cantabile could apply equally to these two textures that give relief from the more percussive, detached, or fugal types of allegro writing that predominate elsewhere in the toccata. The use of the cantabile prompt in this context is part of a mosaic of textures and tempi that alternates more rapidly than is the case in the sonatas of Domenico Scarlatti. But the idea of heightening the contrast between cantabile and brilliant playing has its parallel in Domenico's paired sonatas.

\section{Cantabile and the cembalo con piano e forte}

In considering the genre of the Cantabile sonatas of Scarlatti, today's player must eventually be drawn to the question of instruments: how can the keyboard instruments in Scarlatti's musical environment be said to be playable in a singing style? With our increasing awareness of the Scarlatti family's involvement with the Florentine piano in its early decades, we may ask whether the nuances of piano touch do not lie at the heart of Domenico's Cantabile sonatas.

A useful clue is given by a contemporary of the Scarlatti family, Giovanni M. Casini, reminiscing in 1707 on a gathering which he attended at the request of Prince Ferdinando of Medici in his chambers. He begins by referring to a letter he 


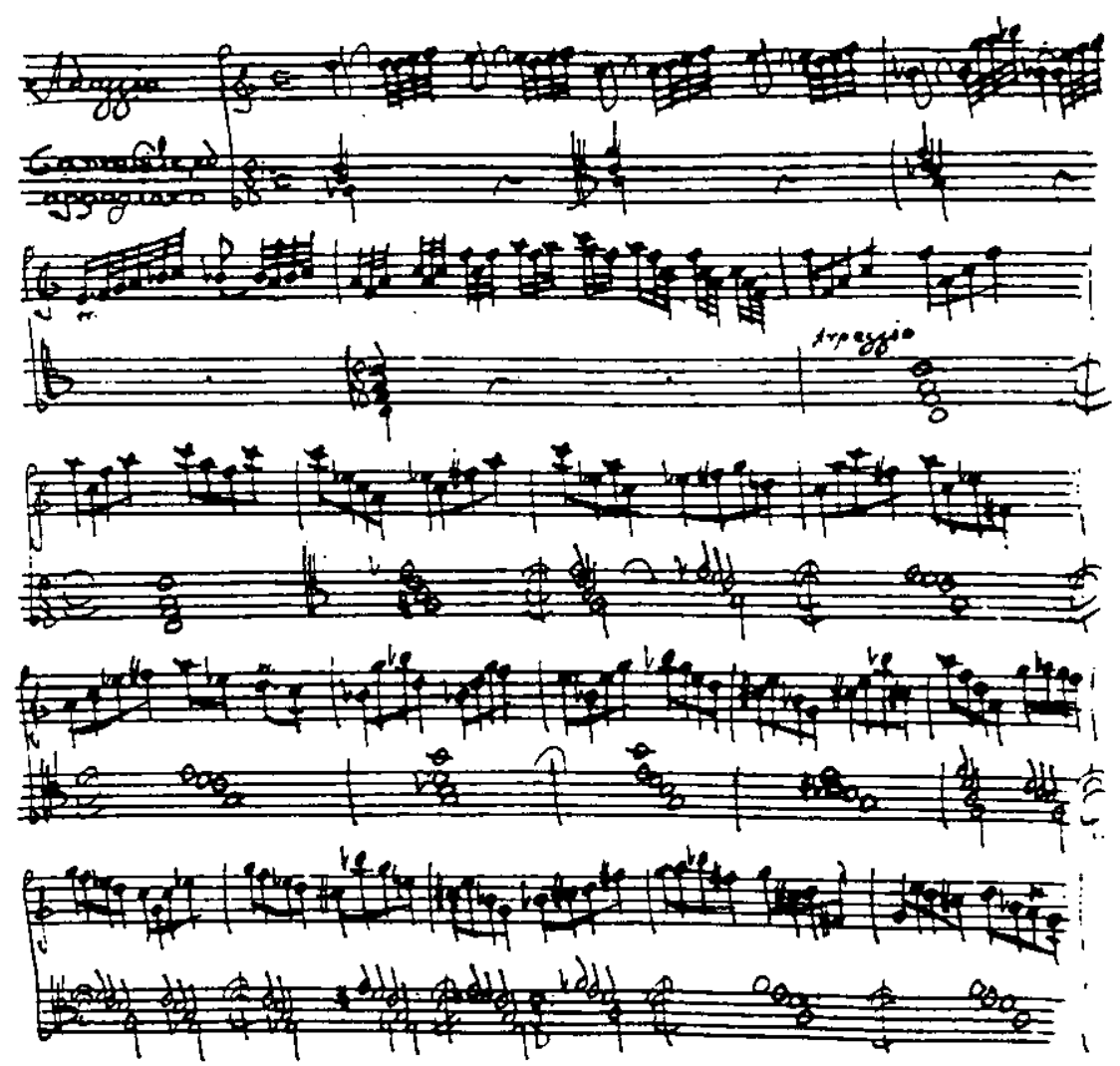

Example 7 A. Scarlatti, Toccata $7^{2}$, primo tono.

Source: Studio per Edizioni Scelte, $198 \mathrm{r}$

was given to read from Alessandro Scarlatti. After an extensive quotation from this letter Casini goes on:

. . dopo varij ragionamenti sulle Musiche e sulle voci da far cantar in quelle, ancora in discussione ci portammo per parlare di come si possa rendere su gli strumenti il parlar del cuore, ora con delicato tocco d'angelo, ora con violenta irruzzione di passioni. E si parlava ancora d'ogni strumento di tasto e di sue limitatezze; e si fini con lodare l'Organo grande e l'Omnicordio di Nigetti e mio.

Si disse che il Cembalo non completa tutto l'esprimere di sentimento umano. Fu qui che Jacomo Perti parlò allora d'istrumenti a cordi uniti in mirabil concerto, e disse che potevano secondare tutto l'humano cuore.

Ma il Serenissimo Principe volle richiamarlo in tema, giachè d'alti'instromenti si parlava, cio è di tasto. Poi si andò tutti a veder gl'istromenti del Serenissimo Signor Principe, e Bartolo Cristofori in spiegazioni si lasciava andare, in spezial modo per quelli modi. (Fabbri, r96r: 107-8)

... after various discussions on music and on voices, we turned to talk about how one could speak on instruments the language of the heart, now with the delicate touch of an angel, now with violent eriptions of passion. And we talked about all sorts of keyboard instruments and their limitations; and finally there was praise for the great organ and the omnicordio of Nigetti and myself. ${ }^{2}$

2. Pagano (1985: 175) explains that the orninicord was a complicated instrument, evidently inspired by Nicolo Vicentino, with each tone divided into 5 parts. 
It was said that the harpsichord could not completely express the whole of human feeling. It was at this point that Jacomo Perti spoke of string instruments united in marvellous concert [ensemble], and he said that it could support the whole of the human heart.

But His most Serene Highness wished to recall the theme, since we were talking about instruments, i.e., about keyboard instruments. Then we all went to see the instruments of His Serene Highness the Prince, and to hear Bartolo Cristofori in his explanations, in his special way by those means.

Where did the Scarlattis stand in this debate, which may well have been frequently conducted in the presence of Prince Ferdinando of Medici, given the close relationship of the Prince to the inventor of the first cembalo col piano e forte? Casini indicates here that Alessandro Scarlatti was an accepted member of this group, referring to him as 'the great musician, my great friend, who was still in Florence, a city that he esteemed virtually as his home, as the true friend of the musical art' (Fabbri 1963: 106).

The question of Domenico's relationship to the new instrument has been treated extensively, and with widely differing conclusions, by Sheveloff (1986), David Sutherland (1995) and John Henry van der Meer (I997). Domenico's awareness of the pianos of Cristofori, and his continued access to them and to similar instruments in the courts of the Iberian peninsula, cannot be doubted. What we lack is evidence of his personal reaction: there are no letters home, like those of Mozart, expressing delight at the tonal or expressive qualities of a certain instrument, nor adverse comments on noisy or inefficient keyboard actions, certainly nothing explicitly comparing the cembalo with the cembalo col piano e forte. But Sutherland (1995: 250) argues that such evidence does exist implicitly, pointing to the regular coincidence between cities where Scarlatti worked and the earliest cultivation of the piano-Florence, Rome, Lisbon, Seville, Madrid.

Occasional indications show Domenico Scarlatti composing with a particular instrument type in mind. There is K. 356 in C major, 'Con spirito andante', for example, with its marking in the Parma Manuscript, 'Per Cembalo expresso''purposely for harpsichord', presumably, though it may just mean 'not for organ', equally a valid choice for a number of the sonatas (Sheveloff $1986: 97-9$ ). A comparatively lengthy work (IIg bars in C with pervasive triplet quaver motion), the piece has much to tell us about techniques and textures deemed by Scarlatti 'per Cembalo expresso'. Some of these are expected, such as the trills in each hand, a third apart; others might be thought more in keeping with a notion of 'piano writing', notably the almost incessant octave writing in both hands in the cadential areas. With its use of extremes of register (GG-g" "), K. 356 inhabits a part of the keyboard not known to have been present on pianos to which Scarlatti had access. It is not the nomenclature Cembalo that specifically excludes the cembalo con piano e forte (a designation which apparently never appears in manuscripts of Domenico's keyboard works): rather, the 5-octave range rules it out.

But if the marking of K. 356 does mean what it seems to-'for harpsichord'-it may imply that in general the sonatas might be played equally on harpsichord or piano, according to the limits of range and availability. It could even mean that the piano was the expected instrument of performance, thus prompting the composer to indicate that he had written a piece specifically for harpsichord.

Recent research on the range of Florentine pianos indicates their limited range in the lifetime of Scarlatti-mostly 49 notes, or $\mathrm{C}-{ }^{\prime \prime}$. Thus it is possible to con- 
Table 2 Scarlatti's Cantabile Sonatas composed within 4 octave range (pre 1740?)

\begin{tabular}{|c|c|c|}
\hline Sonat2, Kirkpatrick no. & Designation & Range \\
\hline K. 144, G major (single) & Cantabile & $D-d \cdots$ \\
\hline $\begin{array}{l}\text { K. i7o, C major } \\
\text { (Andente leads to Allegro) }\end{array}$ & Andante moderato e cantabile/Allegro & $C-d \cdots$ \\
\hline $\begin{array}{l}\text { K. } 176, \mathrm{D} \text { minor } \\
\text { (different tempi } \\
\text { within a singie sonata) }\end{array}$ & Cantabile andante /allegrissimo & $\mathrm{D}-\mathrm{d} \cdots$ \\
\hline $\begin{array}{l}\text { K. } 208, \text { A major } \\
\text { K. 209, A major }\end{array}$ & $\begin{array}{l}\text { Adagio e cantabile } \\
\text { Allegro }\end{array}$ & $\begin{array}{l}G-d^{\prime} \\
E-d^{\cdots}\end{array}$ \\
\hline $\begin{array}{l}\text { K. } 277, \text { D major } \\
\text { K. } 278, D \text { major }\end{array}$ & $\begin{array}{l}\text { Cantabile andantino } \\
\text { Con velocità }\end{array}$ & $\begin{array}{l}D-d^{\cdots} \\
D-d^{\cdots}\end{array}$ \\
\hline $\begin{array}{l}\text { K. } 304, \mathrm{G} \text { major } \\
\text { K. } 305, \mathrm{G} \text { major }\end{array}$ & $\begin{array}{l}\text { Andante cantabile } \\
\text { Allegro }\end{array}$ & $\begin{array}{l}G-d^{\prime \prime} \\
G-d^{\cdots}\end{array}$ \\
\hline $\begin{array}{l}\text { K. } 308, C \text { major } \\
\text { K. } 309, \text { C major }\end{array}$ & $\begin{array}{l}\text { Cantabile } \\
\text { Allegro }\end{array}$ & $\begin{array}{l}\mathrm{C}-\mathrm{c}^{\prime \prime} \\
\mathrm{D} \\
\text { (also GG doubling, } \\
\text { lest chord)-d }{ }^{\prime \prime}\end{array}$ \\
\hline $\begin{array}{l}\text { K. } 347, G \text { minor } \\
\text { K. } 348, G \text { major }\end{array}$ & $\begin{array}{l}\text { Moderato e cantabile } \\
\text { Prestissimo }\end{array}$ & $\begin{array}{l}D-d^{\prime} \cdot \\
C-d^{\prime \prime}\end{array}$ \\
\hline
\end{tabular}

sider the pieces with the range of 4 octaves, and less, as being playable on the Florentine and Iberian pianos at the court of Maria Barbara (see Table 2). Pieces such as K. 208 (G-d") - a mere 3 and a half octaves-come to mind. The range of the pieces composed as a pair or a 'triplet' must be considered here, as van der Meer points out (1997: 140). Here, too, the range of K. 209 fits, with its lowest note going no further than $E$. Whether the recurrent appearance of $d^{\prime \prime \prime}$ as the highest note excludes such pieces from being considered as playable on the piano is a question not specifically answered by Sutherland or van der Meer.

These sonatas consistently show some of the most confined ranges of all Scarlatti's keyboard works, compared with the standard ranges of C-d "', referred to by van der Meer as the 'Portuguese compass', and GG-d"', available to Scarlatti from his time in Spain, c. 1740 (van der Meer 1997: 144-7). In all but 2 cases these Cantabile sonatas and the pieces with which they are paired, belong to the small group of pieces that fit the 4 -octave range of the early Florentine pianos.

Of the sonatas accepted as belonging to Scarlatti's 'later' period of composition (and to Maria Barbara's later period of instrument acquisition), extended ranges are noticeable in the case of the Cantabile sonatas, though they seldom touch upon the full 5-octave range used by Scarlatti frequently elsewhere in his sonatas (see Table 3). The inventory of María Barbara's instruments drawn up as part of her 1756 Last Will and Testament (translated in Sheveloff $1986: 91-2$ ) lists three pianos, including one of 56 keys, i.e. GG-d"', and one with 54 (GG-c"'?) as well as a Florentine clavicordio de piano with the old-fashioned 4 -octave range, kept at Aranjuez, spring residence of the the Royal household. In conclusion, it seems that sonatas with an extension of the higher register, that is, higher than d"', would belong exclusively to the harpsichord; the inferior sound of the piano in the highest register is certainly a strong reason against the extension of the treble at this time. Conversely it may be feasible to imagine sonatas with the range GG-d"' as 
Table 3 Ranges of later Cantabile Sonatas of Scarlarti

\begin{tabular}{|c|c|c|}
\hline $\begin{array}{l}\text { K. } 474, \text { E flat } \\
\text { K. } 475 \text {, E flnt }\end{array}$ & $\begin{array}{l}\text { Andante e cantabile } \\
\text { Aliegrissimo }\end{array}$ & $\begin{array}{l}\text { E flat }- \text { e flat }{ }^{\prime \prime}\left(+d^{\cdots}\right) \\
B B \text { flat }-e^{\prime \prime} \text { flat }+d^{\prime \prime}\end{array}$ \\
\hline $\begin{array}{l}\text { K. } 478, \text { D major } \\
\text { K. } 479, \text { D major } \\
\text { K. } 480, \text { D major }\end{array}$ & $\begin{array}{l}\text { Andante e cantabile } \\
\text { Allegrissimo } \\
\text { Presto }\end{array}$ & $\begin{array}{l}A A+B B-g^{\prime \prime}\left(+f^{\prime \prime}\right) \\
A A+C-g^{\prime \prime}+f(\cdots) \\
A A-g^{\prime \prime}+f^{\prime \prime}\end{array}$ \\
\hline $\begin{array}{l}\mathrm{K} .48 \mathrm{z}, \mathrm{F} \text { minor } \\
\mathrm{K} .48_{2}, \mathrm{~F} \text { major } \\
\mathrm{K} .48_{3}, \mathrm{~F} \text { major }\end{array}$ & $\begin{array}{l}\text { Andante e cantabile } \\
\text { Allegrissimo } \\
\text { Presto }\end{array}$ & 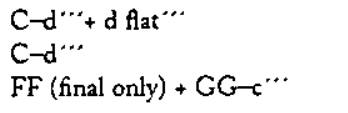 \\
\hline $\mathrm{K} .485, \mathrm{C}$ major & $\begin{array}{l}\text { Andante e cantabile } \\
\text { (RH sixths, LH octaves } \\
\text { semi-glissando } \mathrm{RH} \text { scales) }\end{array}$ & $F F+G G+A A$ flat $-g^{\prime \prime \prime}+f^{\prime \prime}$ \\
\hline $\begin{array}{l}\text { K. } 486, C \text { major } \\
\text { K. } 48, C \text { major }\end{array}$ & $\begin{array}{l}\text { Allegro } \\
\text { Allegro }\end{array}$ & $\begin{array}{l}\text { GG-e"'+e flat"." } \\
\text { GG-d"'. }\end{array}$ \\
\hline $\begin{array}{l}\text { K. } 490, D \text { major } \\
\text { K. } 491, D \text { major } \\
\text { K. } 49^{2}, \mathrm{D} \text { major }\end{array}$ & $\begin{array}{l}\text { Cantabile } \\
\text { Allegro } \\
\text { Presto }\end{array}$ & $\begin{array}{l}A A+B B-d^{\prime \prime} \\
A A(+G G)-d^{\cdots} \\
G G+A A-d^{\cdots}\end{array}$ \\
\hline $\begin{array}{l}\text { K. } 508 \text {, E flat } \\
\text { K. } 509 \text {, E flat }\end{array}$ & $\begin{array}{l}\text { Andante cantabile } \\
\text { Allegro }\end{array}$ & $\begin{array}{l}\text { BB flat - e flat }{ }^{\prime \prime} \\
\text { GG-e flat }{ }^{\cdots}\end{array}$ \\
\hline $\begin{array}{l}\text { K. } 534, D \text { major } \\
\text { K. } 535, D \text { major }\end{array}$ & $\begin{array}{l}\text { Cantabile } \\
\text { Allegro }\end{array}$ & $\begin{array}{l}A A-d \cdots(\text { next lowest note: } D) \\
\text { GG }(+A A+B B)-d^{\prime \prime}+e^{\prime}\end{array}$ \\
\hline $\begin{array}{l}\text { K. } 536, \text { A major } \\
\text { K. } 537 \text {, A major }\end{array}$ & $\begin{array}{l}\text { Cantabile } \\
\text { Prestissimo }\end{array}$ & $\begin{array}{l}A A-d \cdots+e^{\cdots \cdot}+f f^{\cdots} \\
A A+B B-d^{\prime \prime}\end{array}$ \\
\hline $\begin{array}{l}\text { K. } 544, \text { B fiat } \\
\text { K. } 545, \text { B fiat }\end{array}$ & $\begin{array}{l}\text { Cantabile } \\
\text { Prestissimo }\end{array}$ & $\begin{array}{l}\text { BB flat }-c^{\prime \prime}+d \text { flat }{ }^{\prime \prime} \\
\text { GG-d". }\end{array}$ \\
\hline $\begin{array}{l}\text { K. } 546, G \text { minor } \\
\text { K. } 547, G \text { major }\end{array}$ & $\begin{array}{l}\text { Caritabile } \\
\text { Allegro }\end{array}$ & $\begin{array}{l}G G+B B \text { flat }- \text { e flat }{ }^{\prime \prime} \\
G G+A A-\text { e flat }{ }^{\prime \prime}\end{array}$ \\
\hline
\end{tabular}

pieces designed for piano performance. The group of $\mathrm{F}$ minor/major K. $48 \mathrm{I}$ ( F minor), considered to date from Scarlatti's later years, could well be a case in point.

Van der Meer argues against the piano as an instrument of choice for Scarlatti's sonatas, on the grounds of its deficient tone projection in this period. Equally, there seems to be a widespread belief that it is not possible to play in a singing manner on Italian harpsichords. Yet no one who has played or listened to fine Italian harpsichords of the period of Scarlatti can subscribe to this view; recordings such as those of Colin Tilney, made on Italian instruments (1998, 1995), prove the opposite. On these instruments, certainly, it is a challenge to the player to elicit long elegant melodic lines from the harpsichord, to emulate the hypnotic beauty of the singer's slow aria style uninterrupted by the regular accentuation that predominates in the quick tempo sonatas. What is less easy is for the harpsichord to accompany itself.

We may imagine that the potential for sensitive and yielding accompaniment was one of the prime qualities of the new pianos. Current thought is divided on the subject of Scarlatti's relationship with the piano. Van der Meer questions whether one can 'seriously maintain that the pianoforte-at least the Florentine and Iberian type-was the ideal instrument or even one of the ideal instruments for the performance of Scarlatti's solo works' (1997: 155), concluding in the negative. To David Sutherland on the other hand, Scarlatti may have been the agent of 
[the Cristofori pianoforte's] diffusion 'and deserves to be recognized as "the piano's first great advocate" ' (1995: 250, 252).

There may be a way of reconciling these apparently contradictory views. In the cantabile style of Domenico Scarlatti, the prevailing textures only infrequently visit the world of two-part counterpoint or more densely contrapuntal writing, though he relished the demands of fugal composition when drawn to it. Rather, cantabile in his hands is a style of melody and accompaniment, in which the accompaniment style is meticulously thinned and thickened from one beat to be the next. Such shaping of texture does not necessarily require the variation of touch control possible with the new piano: it is part of the skill of accompaniment on the harpsichord, as notated in these pieces by Scarlatti. But it would also be immediately at home on the piano, entering the world of Cristofori's difficult invention with a new style that 'speaks the language of the heart' in its alternation between the 'touch of an angel and violent outbursts of passion'- to quote the Florentine circle.

The novelty of Scarlatti's writing in these pieces lies in the delicately balanced and exquisitely calculated relationship between melodic line and accompaniment. Tied notes in the melodic line and interrupted or extended progressions in the harmonic movement give the impression of an unbroken arc, avoiding the sense of vacuo referred to by Tartini. Maybe Scarlatti's unparalleled skill is his ability to compose with undisputed success for the harpsichord, while at the same time laying down, in his Cantabile sonatas, the lines for the first idiomatic style for the piano.

\section{References}

Bach, C. P. E. (1759, 1762), Versuch über die wabre Art, das Klavier zu spielen, ed. Niemann. Berlin: C. F. Kahnt, facsimile, 1972.

Bach, J. S. (1723), Inventionen und Sinfonien (Anleitung), ed. G. Dadelsen. Bäsel: Bärenreiter,

197. (c. 1947), Brandenburgische Konzerte. Faksimile nach dem im Besitz der Deutscien Staatsbibliothek in Berlin befindichen Autograph. Leipzig: Edition Peters.

Brown, Clive (1999), Classical and Romantic Performing Practice 1750-1900. Oxford: Oxford University Press.

Chafe, Eric (1992), Monterverdi's Tonal Language. New York: Schirmer.

Fabbri, Mario (1961), Alessandro Scarlatti e il Principe Ferdinando de' Medici. Firenze: Leo S. Olschki.

Hammond, Frederick (1994) 'Domenico Scarlatti', in R. Marshall (ed.), Eigbteenth-century Keyboard Music. New York: Schirmer, 1994, pp. 154-90.

Kerman, Joseph (1999), Concerto Conversations. Princeton, NJ: Harvard University Press.

Newton, Richard (r939), 'The English Cult of Domenico Scarlatti', Music and Letters 20, pp. $13^{8}-56$.

Pagano, Roberto (1985), Scarlatti Alessandro e Domenico: due vite in una. Milano: Arnaldo Mondadori.

Quantz, J.-J. (1752), Versucb einer Anweisung, die Flote traversière zu spielen (Reprint of the Berlin edition. Basel: Bärenreiter, 1983).

Sachs, Barbara (199I), 'Scarlatti's tremulo', Early Music Ig: 9I-3.

Scarlatti, Alessandro, Primo e Second Libro di Toccate, Napoli, s.d. ed. Laura Alvini. SPES, Firenze: Studio per Edizioni Scelte, 1981.

Scariatti, Domenico, Sonatas, vols II-XI. ed. K. Gilbert. Paris: Le Pupitre, I971-1984. 
Sheveloff, Joel (1985, 1986) 'Domenico Scarlatti: Tercentenary Frustrations', Musical Quarterly 71,4, pp. 339-436; 72,I, Pp. 90-II8.

Sutherland, David (r995), 'Domenico Scarlatti and the Florentine piano', Early Music 23,2, pp. $243-56$.

Tartini, Giuseppe Traité des Agréments de la Musique 'traduit par le sigt. Denis', Paris 1771, ed. Erwin R. Jacobi, Moeck, Celle, New York, 1960. Translations by Halton from the Italian version, published in facsimile by Jacobi, Regole per arrivere a saper ben suonar il violino, copiato da Giovanni Francesco Nicolai suo Scolaro.

Tilney, Colin (1988), Scarlatti Sonatas. Dorian (DOR - 90103).

- (1995), Scarlatti High and Low. Music and Arts (CD 907).

Tosi, Pier Francesco (r723), Opinioni de' Cantori Antichi e Modernii (Arnoldo Forni, repr. Napoli, 1904); trans. Galliard, 1742, as Observations on the Florid Song, ed. M. Pilkington. London: Stainer \& Bell, rg87.

van der Meer, John Henry (1997), 'The keyboard string instruments at the disposal of Domenico Scarlatti', The Galpin Society Journal 50, pp. 136-60. 